\title{
Knowledge Regarding Coronavirus Disease-19 Related to Nutritional Practices in Residents of Medan City, Indonesia
}

\author{
Debora Natalia $^{1} \mathbb{D}$, Dina Keumala Sari ${ }^{2 *}$ (D), Rizky Adriansyah $^{3}$ (D) Wulan Fadinie $^{4}$ (D) \\ ${ }^{1}$ Medical doctor Study Program, Faculty of Medicine, Universitas Sumatera Utara, Indonesia; ${ }^{2}$ Tropical Medicine Program \\ Study, Faculty of Medicine, Universitas Sumatera Utara, Indonesia; ${ }^{3}$ Department of Child Health, Faculty of Medicine, \\ Universitas Sumatera Utara, H. Adam Malik General Hospital, Medan, Indonesia; ${ }^{4}$ Department of Anesthesiology and \\ Intensive Care, Faculty of Medicine, Universitas Sumatera Utara, H. Adam Malik Central General Hospital, Medan, North \\ Sumatera, Indonesia
}

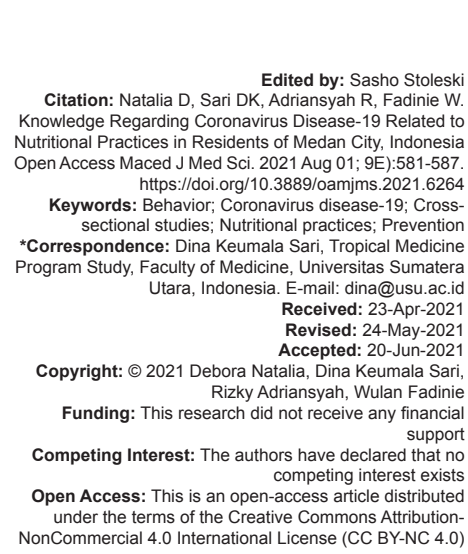

Introduction

In early 2020, the world was shocked by the outbreak of a new type of pneumonia, which started in Wuhan, Hubei Province, and then spread rapidly to more than 190 countries and territories [1]. The World Health Organization (WHO) declared that the world entered a global emergency after the outbreak on January 31, 2020 [2].

This outbreak began in December 2019, when a mysterious pneumonia case was first reported in Wuhan, Hubei Province. The source of the transmission of this case is still uncertain, but the first case was linked to a fish market in Wuhan between December 18 , 2019, and December 29, 2019 [3]. The first two cases of coronavirus disease-2019 (COVID-19) in Indonesia were reported on March 2, 2020, and the number of infections and deaths has continued to increase until now [1].

The samples studied showed the etiology of the new coronavirus. Initially, the disease was temporarily named the 2019 novel coronavirus (2019-nCoV). Then, the WHO announced a new name on February 11,2020 , that is, the COVID-19, based on the severe acute respiratory syndrome coronavirus-2 (SARSCoV-2) (WHO, 2020). COVID-19 is a disease caused by a ribonucleic acid virus, namely, SARS-CoV-2, with a particle size of $120-160 \mathrm{~nm}$ [4]. The SARS-CoV-2 sequence has similarities with the coronavirus isolated in bats, so the hypothesis of Riedel et al. is that SARSCoV-2 originated from bats, which then mutated and infected humans [5]. Common signs and symptoms of COVID-19 infection include acute respiratory symptoms, such as fever, cough, and shortness of breath. In severe cases of COVID-19, it can cause pneumonia, acute respiratory syndrome, kidney failure, and even death [6].

Many efforts had been made in the literature to determine how the body's resistance to respiratory infections could be improved. Some of them were quitting smoking and alcohol consumption, improving sleep quality, and taking supplements [1]. Macro, micro, and phytonutrients in foods, especially colorful fruits 
and vegetables, generally promote a healthy immune response [7]. Diet and nutrition always influence the competence of the immune system and determine the risk and severity of infection. There is a two-way relationship between diet, nutrition, infection, and immunity. A person's nutritional status affects their risk of infection and the clinical course of COVID-19. Therefore, the maintenance of a healthy macro and micronutrient status is an important preventive measure for COVID-19. When a person's nutritional status is improved, either through diet modification or nutritional supplementation, it is very important to determine the clinical course of COVID-19, especially in malnourished individuals [8]. Given the role nutritional status plays in a person's immunity, the evaluation of individual nutrition may be important for preparing a person for the COVID-19 pandemic. Besides, knowledge about COVID-19 is very important. If knowledge about COVID-19 is inadequate, preventing the transmission of the disease will be difficult, and the probability that a person will experience COVID-19 infection will be increased. Based on those reasons, we decided to do this research, the aim of this study was to find relationship among all parameters that affecting nutritional practice. Thus, in this study, whether there is was a relationship between knowledge regarding COVID-19 and nutritional practices in residents of Medan city, Indonesia, which was investigated.

\section{Materials and Methods}

Across-sectional study was conducted between June 2020 and July 2020. The data were collected online, because it was not feasible to do an offline survey. This research was conducted on residents of Medan City, which consists of 21 subdistricts that had been included in the COVID-19 red zone since June 5 , 2020. The population of Medan City, based on a 2018 report, is $2,264,145$ people. The data in the present study were collected from a total of 210 questionnaires. A total of 10 samples from outside the city of Medan were excluded, so the analysis consisted of 200 research samples from Medan City.

The data used in this study were primary data obtained directly by the researcher. The primary data were obtained from people by having them fill out the research questionnaire. A Google Forms was used to collect the data, and the questionnaire was distributed using WhatsApp, Line, and Direct Message Instagram. People who were living in Medan, were aged 18-35 years, understood the use of Google Forms, and were willing to fill out the questionnaire were directed to open the Google Forms link provided and fill out the questionnaire. Research samples outside Medan City would be excluded from this study.
The questionnaire used was taken from previous researches [9], [10] and COVID-19 guideline in Indonesia [11], but only the knowledge variable was used. The questionnaire was translated, and a validity test was conducted using product moment correlation techniques (significance $<0.05)$. The reliability was also tested using Cronbach's $\alpha$ (Cronbach $\alpha=0.769)$. For the data analysis, each correct answer was given a value of 1 , while an incorrect answer was given a value of 0 . To assess nutritional behavior, the questionnaire used was taken from previous research on balanced nutrition. The questionnaire consisted of 13 questions, with 1 question excluded. The assessment of nutritional behavior consisted of a score of $4=$ often, a score of $3=$ sometimes, a score of 2 = rarely, and a score of $1=$ never. From the data collection results, a $75 \%$ score was considered good, 56-74\% was considered satisfactory, and $<55 \%$ was considered poor.

We used the SPSS program (version 24; SPSS Inc., Chicago, IL, USA) to perform the analysis. The descriptive analysis was reported as the frequency, percentage, and mean scores. The knowledge scores and practices of different persons, according to the demographic characteristics, were compared using an independent samples t-test, one-way analysis of variance, Mann-Whitney U-test, and Kruskal-Wallis test.

To determine differences in the level of knowledge of COVID-19 and nutritional behavior based on demographic characteristics, the Chi-square test and Fisher's exact test were used. To show the relationship between knowledge and attitudes, the Chisquared test was used. Linear regression analysis was applied with an odds ratio and $95 \%$ confidence interval (CI) to find possible determinants of good knowledge regarding COVID-19 and health practice. $p<0.05$ was considered statistically significant in all tests.

\section{Results}

The data in the present study were collected from a total of 210 questionnaires. A total of 10 samples from outside the city of Medan were excluded, so the analysis consisted of 200 research samples from Medan City. In this final sample, there were 128 women $(64 \%)$ and 172 people (86\%) aged 18-25 years old, with an average age of 21.98 years. Most of the research samples were from residents of Medan Kota, and the highest education level was senior high school. The characteristics of the respondents are shown in Table 1.

More than $90 \%$ of the respondents had a good understanding of the following points relating to COVID-19: COVID-19 is a disease caused by a virus $(97.5 \%)$; transmission of COVID-19 can occur through 
Table 1: Demographic characteristic of the respondents

\begin{tabular}{ll}
\hline Characteristics & Frequency, $\mathrm{n}(\%)$ \\
\hline Gender & \\
Male & $72(36)$ \\
Female & $128(64)$ \\
Age group (years) & \\
18-25 & $172(86)$ \\
$26-35$ & $28(14)$ \\
Subdistrict & \\
Medan Amplas-Medan Denai & $73(36.5)$ \\
Medan Helvetia-Medan Perjuangan & $79(39.5)$ \\
Medan Petisah-Medan Tuntungan & $48(24)$ \\
Education & \\
Senior high school & $142(71)$ \\
College/university & $58(29)$ \\
Occupation & \\
Unemployed & $49(24.5)$ \\
Entrepreneur & $14(7)$ \\
Public servant & $4(2)$ \\
Private employees & $63(31.5)$ \\
Student & $56(28)$ \\
Teacher & $11(5.5)$ \\
Others & $2(1.0)$ \\
Income & \\
Low & $87(43.5)$ \\
Middle & $33(16.5)$ \\
High & $37(18.5)$ \\
Very high & $43(21.5)$ \\
Source of COVID-19 information & \\
Journal/articles and case report & $3(1.5)$ \\
Local government & $3(1.5)$ \\
Mass media & $59(19.5)$ \\
Social media & $113(56.5)$ \\
Parents/friends/relatives & $18(9)$ \\
Local health workers/expert visits & $4(12)$ \\
\hline COVID: Coronavirus disease. & \\
&
\end{tabular}

close contact (95.5\%) and respiratory droplets (99\%); there are greater risk factors associated with elderly individuals (94\%); fever, cough, sore throat, and shortness of breath are symptoms that can be found in COVID-19 (94.5\%); infection can be prevented through washing hands and using face masks (98.5\%); infection can be prevented by avoiding traveling to crowded places (98\%); children and young adults need to be involved in the prevention of COVID-19 (91\%); and infection can be effectively prevented through isolation $(96.5 \%)$ and the isolation of COVID-19 contacts (97.5\%) (Table 2).

In terms of nutritional practices, some Medan residents often pay attention to body weight $(21.5 \%)$; eat a variety of foods $(30.5 \%)$; eat 3 times a day $(52.5 \%)$; eat fruit $(13,5 \%)$ and vegetables $(24 \%)$ properly; consume animal protein (29\%); consume protein properly $(33.5 \%)$; reduce their consumption of sweet, salty, and fatty foods (19.5\%); drink eight glasses of water a day $(58.5 \%)$; read food packaging labels $(45.5 \%)$; wash hands before eating $(74.5 \%)$; and do physical activities (18.5\%). These results can be found in Table 3.

There was no significant difference between the respondents in the mean score for knowledge of COVID-19 and nutritional practices based on certain demographic characteristics (Table 4).

In addition, there was no significant difference between the respondents based on other demographic characteristics in the level of knowledge and behavior, except for education, with a knowledge score of $p=0.033$ (Table 5). An analysis was conducted using the Spearman's rho test. A relationship between education and knowledge toward COVID-19 was shown, with a
Table 2: Knowledge regarding COVID-19 questionnaire

\begin{tabular}{|c|c|c|c|}
\hline No. & Questions (Answer) & $\begin{array}{l}\text { Correct answer, } \\
\mathrm{n}(\%)\end{array}$ & $\begin{array}{l}\text { Wrong } \\
\text { answer, n (\%) }\end{array}$ \\
\hline 1. & $\begin{array}{l}\text { COVID-19 is a disease caused by a viral infection } \\
\text { (True) }\end{array}$ & 195 (97.5) & $5(2.5)$ \\
\hline 2 & $\begin{array}{l}\text { COVID-19 can be transmitted through close } \\
\text { contact with an infected individual (True) }\end{array}$ & $191(95.5)$ & $9(4.5)$ \\
\hline 3. & $\begin{array}{l}\text { COVID-19 can spread through respiratory } \\
\text { droplets from infected individuals (True) }\end{array}$ & 198 (99) & $2(1)$ \\
\hline 4. & $\begin{array}{l}\text { Not everyone with COVID-19 has severe } \\
\text { symptoms. In elderly individuals, the risk of } \\
\text { having severe symptoms is higher (True) }\end{array}$ & $188(94)$ & $12(6)$ \\
\hline 5. & $\begin{array}{l}\text { Fever, cough, sore throat, and shortness of breath } \\
\text { are symptoms that can be found in COVID-19 } \\
\text { (True) }\end{array}$ & $189(94.5)$ & $11(5.5)$ \\
\hline 6. & $\begin{array}{l}\text { The main symptoms of COVID-19 are fever, } \\
\text { diarrhea, and skin rashes (False) }\end{array}$ & $95(47.5)$ & $105(52.5)$ \\
\hline 7. & $\begin{array}{l}\text { Antibiotics are the main (first line) treatment for } \\
\text { COVID-19 (False) }\end{array}$ & $54(27)$ & $146(73)$ \\
\hline 8. & $\begin{array}{l}\text { Supportive treatment (giving fluids, ventilator, } \\
\text { close monitoring of the patient, etc.) can help } \\
\text { COVID-19 patients recover (True) }\end{array}$ & $154(77)$ & $46(23)$ \\
\hline 9. & $\begin{array}{l}\text { Washing hands with soap and water and using a } \\
\text { face mask can help prevent the transmission of } \\
\text { COVID-19 (True) }\end{array}$ & $197(98.5)$ & $3(1.5)$ \\
\hline 10. & $\begin{array}{l}\text { Children and young adults do not need to } \\
\text { be involved in the prevention of COVID-19 } \\
\text { transmission (False) }\end{array}$ & $182(91)$ & $18(9)$ \\
\hline 11. & $\begin{array}{l}\text { To prevent the transmission of COVID-19, } \\
\text { traveling to crowded places, such as malls and } \\
\text { public transportation, must be avoided (True) }\end{array}$ & $196(98)$ & $4(2)$ \\
\hline 12 & $\begin{array}{l}\text { Individuals who have had contact with COVID- } \\
19 \text { positive patients must be isolated in an } \\
\text { appropriate place immediately. In general, the } \\
\text { length of isolation should be } 14 \text { days (True) }\end{array}$ & 195 (97.5) & $5(2.5)$ \\
\hline 13. & $\begin{array}{l}\text { Isolation and treatment of COVID-19 patients } \\
\text { is an effective way to reduce the spread of the } \\
\text { virus (True) }\end{array}$ & $193(96.5)$ & $7(3.5)$ \\
\hline
\end{tabular}

significance value of $0.016(p<0.05)$ with a correlation value of 0.171 .

The relationship between knowledge of COVID-19 and nutritional practices has $p=0.022$. Because $p<0.05$, the hypothesis that there is a relationship between the level of knowledge about COVID-19 and nutritional practices in the general public in Medan City is accepted. Furthermore, the results of the linear regression test showed that an increase of $1 \%$ in knowledge increases the value for behavior associated with balanced nutrition by 0.244 (Table 6). An analysis was conducted using the Spearman's rho test. A relationship between knowledge towards COVID-19 and nutrition practices was shown, with a significance value of $0.022(p<0.05)$ with a correlation value of 0.161

\section{Discussion}

As of September 2020, COVID-19 cases are still increasing and continue to be a significant concern in public health. Knowledge regarding COVID-19 is an important factor for the formation of individual nutritional practices. When nutritional status is improved, it is very important to determine the clinical course of COVID-19.

Female respondents participated more readily in the research, with as many as 128 women volunteering for the questionnaire and only 72 male 
Table 3: Nutritional practices results

\begin{tabular}{|c|c|c|c|c|c|}
\hline No. & Question & Frequently, $\mathrm{n}(\%)$ & Sometimes, n (\%) & Rarely, n (\%) & Never, n (\%) \\
\hline 1. & In order to maintain a normal weight, I regularly pay attention to weight gain & $43(21.5)$ & $86(43)$ & $46(23)$ & $25(12.5)$ \\
\hline 2. & In order to achieve my ideal nutritional status, I consume a wide variety of foods & $61(30.5)$ & $93(46.5)$ & $38(19)$ & $8(4)$ \\
\hline 3. & To meet the nutritional needs for a day, I regularly eat 3 times a day & $105(52.5)$ & $53(26.5)$ & $33(16.5)$ & $9(4.5)$ \\
\hline 4. & I consume fruit at least 2 times a day & $27(13.5)$ & $58(29)$ & $93(46.5)$ & $22(11)$ \\
\hline 5. & I consume vegetables at least 3 times a day & $48(24)$ & 77 (38.5) & $54(27)$ & $21(10.5)$ \\
\hline 6. & I consume animal protein and plant protein at least 2 times a day & $67(33.5)$ & $84(42)$ & $41(20.5)$ & $8(4)$ \\
\hline 7. & In order not to suffer from anemia, I consume animal protein & $58(29)$ & $87(43.5)$ & $38(19)$ & $17(8.5)$ \\
\hline 8. & I reduce the consumption of sweet, salty, and fatty foods & 39 (19.5) & $71(35.5)$ & $71(35.5)$ & $19(9.5)$ \\
\hline 9. & I drink eight glasses of water a day & $117(58.5)$ & $55(27.5)$ & $25(12.5)$ & $3(1.5)$ \\
\hline 10. & I read the labels on food packaging before buying products & $91(45.5)$ & $56(28)$ & 37 (18.5) & $16(8)$ \\
\hline 11. & Before eating and drinking, I wash my hands & $149(74.5)$ & 39 (19.5) & $12(6)$ & $0(0)$ \\
\hline 12. & I do physical exercise or sports for at least $30 \mathrm{~min}$ a day & $37(18.5)$ & $71(35.5)$ & $72(36)$ & $20(10)$ \\
\hline
\end{tabular}

Table 4: Differences in the mean scores for COVID-19 knowledge and nutritional practices based on demographic characteristics

\begin{tabular}{|c|c|c|c|c|}
\hline \multirow[t]{2}{*}{ Variables } & \multicolumn{2}{|c|}{ COVID-19 knowledge } & \multicolumn{2}{|c|}{ Nutritional practices } \\
\hline & Mean (SD) & p-value & Mean (SD) & p-value \\
\hline \multicolumn{5}{|l|}{ Gender } \\
\hline Male & $10.97(1.80)$ & 0.488 & $36.25(4.70)$ & 0.623 \\
\hline Female & $11.23(1.26)$ & & $35.44(5.78)$ & \\
\hline \multicolumn{5}{|l|}{ Age (years) } \\
\hline $18-25$ & $11.10(1.54)$ & 0.572 & $35.62(5.49)$ & 0.557 \\
\hline $26-35$ & $11.32(1.02)$ & & $36.43(5.01)$ & \\
\hline \multicolumn{5}{|l|}{ Subdistricts } \\
\hline Medan Amplas-Medan Denai & $10.96(1.83)$ & 0.609 & $36.01(4.68)$ & 0.057 \\
\hline Medan Helvetia-Medan Perjuangan & $11.29(1.18)$ & & $36.42(5.72)$ & \\
\hline Medan Petisah-Medan Tuntungan & $11.15(1.32)$ & & $34.17(5.73)$ & \\
\hline \multicolumn{5}{|l|}{ Education } \\
\hline Senior high school & $11.23(1.5)$ & 0.124 & $35.49(5.38)$ & 0.243 \\
\hline College/university & $10.90(1.41)$ & & $36.33(5.51)$ & \\
\hline \multicolumn{5}{|l|}{ Occupation } \\
\hline Unemployed & $11.20(1.17)$ & 0.682 & $35.61(5.28)$ & 0.268 \\
\hline Entrepreneur & $11.07(1.07)$ & & $34.29(5.33)$ & \\
\hline Public servant & $11.25(1.50)$ & & $39.00(0.00)$ & \\
\hline Private employees & $10.84(1.92)$ & & $35.19(5.16)$ & \\
\hline Student & $11.43(1.14)$ & & $36.57(5.44)$ & \\
\hline Teacher & $11.09(1.86)$ & & $34.55(7.05)$ & \\
\hline Others & $11.00(1.48)$ & & $40.00(8.72)$ & \\
\hline \multicolumn{5}{|l|}{ Income } \\
\hline Low & $11.30(1.17)$ & 0.758 & $35.83(5.48)$ & 0.354 \\
\hline Middle & $10.91(2.28)$ & & $36.67(5.48)$ & \\
\hline High & $11.16(1.17)$ & & $36.03(4.96)$ & \\
\hline Very high & $10.95(1.51)$ & & $34.56(5.57)$ & \\
\hline \multicolumn{5}{|l|}{ Source of COVID-19 information } \\
\hline Journal/articles and case report & $12.67(0.58)$ & 0.073 & 37.67() & 0.434 \\
\hline Local government & $11.67(0.58)$ & & $38.00(0.00)$ & \\
\hline Mass media & $11.24(1.91)$ & & $36.22(4.92)$ & \\
\hline Social media & $11.07(1.22)$ & & $35.58(5.84)$ & \\
\hline Parents/friends/relatives & $10.78(1.40)$ & & $33.83(4.85)$ & \\
\hline Local health workers/expert visits & $11.50(1.48)$ & & $38.25(2.06)$ & \\
\hline
\end{tabular}

respondents. The same result was found in several other studies [9], [10], [12], [13].

The number of respondents who had a low income is in line with the occupation of respondents, who were students or unemployed. Social media has an important role, if used responsibly and appropriately, in the rapid and effective dissemination of important information. As for sources of information about COVID-19, most were from social media and mass media. Thus, social media and mass media have an important role to play in spreading information about COVID-19 [9], [14], [15]. However, some studies found that social media can have some drawbacks. Among the drawbacks are the possibility that the information submitted is out-of-date, has never been expertly reviewed, is invalid or incorrect, does not apply to a particular environment, or is even fake [16], [17]. Thus, questions regarding the myths and perceptions of COVID-19 need to be measured as well.

Research on COVID-19 knowledge has been carried out several times, especially in Indonesia
[12], [13] and several other Asian countries, such as the Philippines, Saudi Arabia, China, Vietnam, and Pakistan [9], [10], [18], [19], [20]. Most respondents had a good level of knowledge. The results of this study are in line with those presented in the previous studies [9], [10]. Understanding of the treatment of COVID-19 is still lacking, even though the respondents had a good understanding of the transmission, symptoms, and prevention of COVID-19. There was a difference between this study and the research of Saefi et al. (2020). In that study, most of the respondents did not know that COVID-19 was caused by a coronavirus. However, in this study, the term used was "COVID-19 is caused by a virus." This shows that using different terms can produce different results. Good knowledge might be related to demographic characteristics, but there was no significant difference in the mean score of knowledge and good knowledge based on demographic characteristics.

Besides, one study showed that gender, age, educational background, professional background, health status, and living environment, as well as the level of knowledge and attitudes of the community, could influence nutritional practices. Along with the development of technology, people could access information regarding nutritional practices through social media and mass media [21]. However, the results of this study indicate that there is no significant difference between nutritional practices and demographic characteristics.

During the COVID-19 pandemic, people could also change their nutritional practices, for example, they might increase their consumption of vegetables, fruit, and water and reduce their consumption of sugary drinks and snacks [21]. However, other studies found that the quarantine period might cause depression, stress, and anxiety disorders, which could trigger the consumption of high-sugar foods and reduce physical activity [22]. The quarantine period in Medan City was still ongoing in June 2020 , and a new normal period was effective on July 1 , 2020. A statement by Mattioli et al. (2020) stating that at the end of the quarantine period, the economic crisis could prolong or worsen this poor lifestyle and lead to an increased risk of cardiovascular disease.

In this study, people tended to have good nutritional practices. This result was not consistent with a previous study, which found that most samples had satisfactory nutritional practices [23]. The respondents 
Table 5: Differences in results for COVID-19 knowledge and nutritional practices based on demographic characteristics

\begin{tabular}{|c|c|c|c|c|c|c|c|c|}
\hline \multirow[t]{2}{*}{ Variables } & \multicolumn{4}{|c|}{ COVID-19 knowledge, $\mathrm{n}(\%)$} & \multicolumn{4}{|c|}{ Nutritional practices, $\mathrm{n}(\%)$} \\
\hline & Good & Satisfactory & Poor & $p$-value & Good & Satisfactory & Poor & $p$-value \\
\hline \multicolumn{9}{|l|}{ Gender } \\
\hline Male & $61(30.5)$ & $10(5)$ & $1(0.5)$ & \multirow{2}{*}{0.487} & $44(22)$ & $28(14)$ & $00)$ & \multirow[t]{2}{*}{0.057} \\
\hline Female & $115(57.5)$ & $12(6)$ & $1(0.5)$ & & $74(37)$ & $45(22.5)$ & $9(4.5)$ & \\
\hline \multicolumn{9}{|l|}{ Age (years) } \\
\hline $18-25$ & $150(75)$ & $20(10)$ & $2(1)$ & \multirow{2}{*}{0.812} & $100(50)$ & $63(31.5)$ & $9(4.6)$ & \multirow{2}{*}{0.603} \\
\hline $26-35$ & $26(13)$ & $2(1)$ & $0(0)$ & & $18(9)$ & $10(5)$ & $0(0)$ & \\
\hline \multicolumn{9}{|l|}{ Sub-district } \\
\hline Medan Amplas-Medan Denai & $60(30)$ & $12(6)$ & $1(0.5)$ & \multirow[t]{3}{*}{0.112} & $43(21.5)$ & $28(14)$ & $2(1)$ & \multirow[t]{3}{*}{0.268} \\
\hline Medan Helvetia-Medan Perjuangan & $74(37)$ & $4(2)$ & $1(0.5)$ & & $52(26)$ & $23(11.5)$ & $4(2)$ & \\
\hline Medan Petisah-Medan Tuntungan & $42(21)$ & $6(3)$ & $0(0)$ & & $23(11.5)$ & $22(11)$ & $3(1.5)$ & \\
\hline \multicolumn{9}{|l|}{ Education } \\
\hline Senior high school & $130(65)$ & $11(5.5)$ & $1(0.5)$ & \multirow[t]{2}{*}{0.033} & $80(40)$ & $55(27.5)$ & $7(3.5)$ & \multirow[t]{2}{*}{0.526} \\
\hline College/university & $46(23)$ & $11(5.5)$ & $1(0.5)$ & & $38(19)$ & $18(9)$ & $2(1)$ & \\
\hline \multicolumn{9}{|l|}{ Occupation } \\
\hline Unemployed & $43(21.5)$ & $6(3)$ & $0(0)$ & \multirow[t]{7}{*}{0.195} & $28(14)$ & $20(10)$ & $1(0.5)$ & \multirow[t]{7}{*}{0.463} \\
\hline Entrepreneur & $13(6.5)$ & $1(0.5)$ & $0(0)$ & & $5(2.5)$ & $8(4)$ & $1(0.5)$ & \\
\hline Public servant & $3(1.5)$ & $1(0.5)$ & $0(0)$ & & $4(2)$ & $0(0)$ & $0(0)$ & \\
\hline Private employee & $51(25.5)$ & $11(5.5)$ & $1(0.5)$ & & $35(17.5)$ & $24(12)$ & $4(2)$ & \\
\hline Student & $53(26.5)$ & $3(1.5)$ & $0(0)$ & & $38(19)$ & $16(8)$ & $2(1)$ & \\
\hline Teacher & $10(5)$ & $0(0)$ & $1(0.5)$ & & $6(3)$ & $4(2)$ & $1(0.5)$ & \\
\hline Other & $3(1.5)$ & $0(0)$ & $0(0)$ & & $2(1)$ & $1(0.5)$ & $0(0)$ & \\
\hline \multicolumn{9}{|l|}{ Income } \\
\hline Low & 79 (39.5) & $8(4)$ & $0(0)$ & \multirow[t]{4}{*}{0.398} & $52(26)$ & $31(15.5)$ & $4(2)$ & \multirow[t]{4}{*}{0.927} \\
\hline Middle & $28(14)$ & $4(2)$ & $1(0.5)$ & & $21(10.5)$ & $11(5.5)$ & $1(0.5)$ & \\
\hline High & $34(17)$ & $3(1.5)$ & $0(0)$ & & $23(11.5)$ & $13(6.5)$ & $1(0.5)$ & \\
\hline Very high & $35(17.5)$ & $7(3.5)$ & $1(0.5)$ & & $22(11)$ & $18(9)$ & $3(1.5)$ & \\
\hline \multicolumn{9}{|l|}{ Source of COVID-19 information } \\
\hline Journal/articles and case report & $3(1.5)$ & $0(0)$ & $0(0)$ & \multirow[t]{6}{*}{0.613} & $2(1)$ & $1(0.5)$ & $0(0)$ & \multirow[t]{6}{*}{0.195} \\
\hline Local government & $3(1.5)$ & $0(0)$ & $0(0)$ & & $3(1.5)$ & $0(0)$ & $0(0)$ & \\
\hline Mass media & $53(26.5)$ & $5(2.5)$ & $1(0.5)$ & & $34(17)$ & $24(12)$ & $1(0.5)$ & \\
\hline Social media & $100(50)$ & $12(6)$ & $1(0.5)$ & & $69(34.5)$ & $37(18.5)$ & $7(3.5)$ & \\
\hline Parents/friends/relatives & $14(7)$ & $4(2)$ & $0(0)$ & & $6(3)$ & $11(5.5)$ & $1(0.5)$ & \\
\hline Local health workers/expert visits & $3(1.5)$ & $1(0.5)$ & $0(0)$ & & $4(2)$ & $0(0)$ & $0(0)$ & \\
\hline
\end{tabular}

Table 6: Relationship between COVID-19 knowledge and nutritional practices

\begin{tabular}{llllll}
\hline COVID-19 knowledge & \multicolumn{2}{l}{ Nutritional practices } & & p-value & PR \\
\cline { 2 - 5 } & Good, $\mathrm{n}(\%)$ & Satisfactory-poor, $\mathrm{n}(\%)$ & Total, $\mathrm{n}(\%)$ & & \\
\hline Good & $109(54.4)$ & $67(33.5)$ & $176(88)$ & 0.022 & 2.711 \\
Satisfactory-poor & $9(4.5)$ & $15(7.5)$ & $24(12)$ & \\
Total & $118(59)$ & $82(41)$ & $200(100)$ & & \\
\hline COVID: Coronavirus disease, Cl: Confidence interval. & & & \\
\hline
\end{tabular}

paid the most attention to the importance of washing their hands, eating regularly 3 times a day, and drinking eight glasses of water a day. This might be due to the role of social media and mass media in disseminating information about the importance of hand washing and the existing lifestyle of the community. Physical activity also needs to be promoted in order to improve the body's immune condition [24].

This study has some limitations which were this study conducted in local area and the samples dominated by female gender. Several variables that were not included in the study may affect nutritional practices, namely, attitudes, perceptions, and beliefs. In addition, to determine whether the changes in nutritional practices were due to the changing circumstances, data on nutritional practices before and after the COVID-19 pandemic are needed.

\section{Conclusions}

The relationship between the level of knowledge about COVID-19 and nutritional practices was investigated in this study. In other words, people with proper knowledge about COVID-19 will do proper nutrition practices according to the knowledge they have. The existence of this relationship also indicates that improved nutritional practices may lead to a stronger immune system and a reduced risk of chronic disease and other infectious diseases. However, the infection rate and mortality of COVID-19 have so far continued to increase in Medan. Public awareness about efforts to prevent the transmission of COVID-19 is also needed in addition to implementing good nutritional practices.

\section{Acknowledgments}

We thank to the cooperation and support of all the respondents for the time and effort that they devoted to the study.

\section{Authors' Contributions}

D.N.: Manuscript preparation, data analysis, and manuscript editing. D.K.S: Design, concepts, 
clinical studies, and manuscript review. R.A.: Statistical analysis. W.A.: Literature search and manuscript editing.

\section{Ethics Approval and Consent to Participate}

This study was conducted according to the guidelines laid down in the Declaration of Helsinki and all procedures involving research study participants were approved by the Universitas Sumatera Utara Ethical Committee, No. 103/KEP/USU/2020. Written and verbal informed consent was obtained from all subjects for this study. Verbal consent was witnessed and formally recorded. All participants were aware of the whole process in this study.

\section{References}

1. Susilo A, Rumende CM, Pitoyo CW, Santoso WD, Yulianti M, Sinto R, et al. Coronavirus Disease 2019 : Review of Current Literatures. J Penyakit Dalam Indones. 2020;7(1):45-67. http:// doi.org/10.7454/jpdi.v7i1.415

2. World Health Organization. 2019-nCoV Outbreak is an Emergency of International Concern; 2020. Available from: http://www.euro.who.int/en/health-topics/health-emergencies/ international-health-regulations/news/news/2020/2/2019-ncovoutbreak-is-an-emergency-of-international-concern. [Last accessed on 2020 Nov 04].

3. Rothan HA, Byrareddy SN. The epidemiology and pathogenesis of coronavirus disease (COVID-19) outbreak. J Autoimmun. 2020;109:102433. https://doi.org/10.1016/j.jaut.2020.102433 PMid:32113704

4. Riedel S, Morse SA, Mietzner T, Miller S. Jawetz Melnick and Aldelberg's Medical Microbiology. $28^{\text {th }}$ ed., New York: McGrawHill Education/Medical; 2019.

5. Zhou P, Yang XL, Wang XG, Hu B, Zhang L, Zhang W, et al. A pneumonia outbreak associated with a new coronavirus of probable bat origin. Nature. 2020;579(7798):270-3. https://doi. org/10.1038/s41586-020-2012-7

PMid:32015507

6. Kementrian Kesehatan RI. Pedoman Kesiapsiagaan Menghadapi Coronavirus Disesase (COVID-19), Pedoman Pencegahan Dan Pengendalian COVID-19. Available from: https://www.infeksiemerging.kemkes.go.id/document/ pedoman-pencegahan-dan-pengendalian-covid-19/view. [Last accessed on $2021 \mathrm{Feb}$ 16].

7. Calder PC, Carr AC, Gombart AF, Eggersdorfer M. Optimal nutritional status for a well-functioning immune system is an important factor to protect against viral infections. Nutrients. 2020;12(4):1181. https://doi.org/10.3390/nu12041181 PMid:32340216

8. Gasmi A, Norr S, Tippairote T, Dadar M, Menzel A, Bjørklund G. Individual risk management strategy and potential therapeutic options for the COVID-19 pandemic. Clin Immunol. 2020;215:108409. https://doi.org/10.1016/j.clim.2020.108409

\section{PMid:32276137}

9. Giao H, Le An P, Thi Ngoc Han N, Van Khanh T, Kim Ngan V, Van Tam V. Knowledge and attitude toward COVID-19 among healthcare workers at District 2 Hospital, Ho Chi Minh City. Asian Pac J Trop Med. 2020;13(6):6-11. https://doi. org/10.4103/1995-7645.280396

10. Zhong BL, Luo W, Li HM, Zhang QQ, Liu XG, Li WT, et al. Knowledge, attitudes, and practices towards COVID-19 among Chinese residents during the rapid rise period of the COVID-19 outbreak: A quick online cross-sectional survey. Int J Biol Sci. 2020;16(10):1745-52. https://doi.org/10.7150/ijbs.45221 PMid:32226294

11. PDPI. Pneumonia COVID-19: Diagnosis dan Penatalaksanaan di Indonesia. Available from: https://www.covid19.idionline. org/wp-content/uploads/2020/04/5.-Buku-PDPI-.pdf. [Last accessed on 2021 Feb 16].

12. Sari DK, Amelia R, Dharmajaya R, Sari LM, Fitri NK. Positive correlation between general public knowledge and attitudes regarding COVID-19 outbreak 1 month after first cases reported in Indonesia. J Community Health. 2020;46(1):182-9. https:// doi.org/10.1007/s10900-020-00866-0

PMid:32583360

13. Saefi M, Fauzi A, Kristiana E, Adi WC, Muchson M, Setiawan ME, et al. Survey data of COVID-19-related knowledge, attitude, and practices among Indonesian undergraduate students. Data Brief. 2020;31:105855. https://doi.org/10.1016/j.dib.2020.105855 PMid:32607405

14. Chan AK, Nickson CP, Rudolph JW, Lee A, Joynt GM. Social media for rapid knowledge dissemination: Early experience from the COVID-19 pandemic. Anaesthesia. 2020;75(12):157982. https://doi.org/10.1111/anae.15057 PMid:32227594

15. Reuben RC, Danladi MM, Saleh DA, Ejembi PE. Knowledge, attitudes and practices towards COVID-19: An epidemiological survey in North-Central Nigeria. J Community Health. 2020;46(3):1-14. https://doi.org/10.1007/s10900-020-00881-1 PMid:32638198

16. Geldsetzer P. Using Rapid Online Surveys to Assess Perceptions during Infectious Disease Outbreaks: A Cross-sectional Survey on COVID-19 among the General Public in the United States and United Kingdom. New York: MedRxiv; 2020. https://doi. org/10.1101/2020.03.13.20035568

17. González-Padilla DA, Tortolero-Blanco L. Social media influence in the COVID-19 pandemic. Int Braz J Urol. 2020;46(Suppl 1):120-4. https://doi.org/10.1590/S1677-5538. IBJU.2020.S121

PMid:32550706

18. Al-Hanawi MK, Angawi K, Alshareef N, Qattan AM, Helmy HZ, Abudawood $\mathrm{Y}$, et al. Knowledge, attitude and practice toward COVID-19 among the public in the kingdom of Saudi Arabia: A cross-sectional study. Front Public Health. 2020;8:217. https:// doi.org/10.3389/fpubh.2020.00217

PMid:32574300

19. Lau LL, Hung N, Go DJ, Ferma J, Choi M, Dodd W, et al. Knowledge, attitudes and practices of COVID-19 among incomepoor households in the Philippines: A cross-sectional study. J Glob Health. 2020;10(1):011007. https://doi.org/10.7189/ JOGH.10.011007 PMid:32566169

20. Afzal MS, Khan A, Qureshi UU, Saleem S, Saqib MA, Shabbir RM, et al. Community-based assessment of knowledge, attitude, practices and risk factors regarding COVID-19 among Pakistanis residents during a recent outbreak: A cross-sectional survey. J Community Health. 2020;46(3):476-86. https://doi. org/10.1007/s10900-020-00875-z 
PMid:32661860

21. Luo $Y$, Chen L, Xu F, Gao X, Han D, Na L. Investigation on knowledge, attitudes and practices about food safety and nutrition in the China during the epidemic of corona virus disease 2019. Public Health Nutr. 2020;24(2):267-74. https:// doi.org/10.1017/s1368980020002797

PMid:32669149

22. Mattioli AV, Sciomer S, Cocchi C, Maffei S, Gallina S. Quarantine during COVID-19 outbreak: Changes in diet and physical activity increase the risk of cardiovascular disease. Nutr Metab Cardiovasc Dis. 2020;30(9):1409-17. https://doi.org/10.1016/j. numecd.2020.05.020
PMid:32571612

23. Nurdzulqaidah R. Relationship Between Nutritional Knowledge towards Nutrition Practices in Students from Faculty of Medicine Islamic University Bandung Class of 2013. Prosiding Pendidikan Dokter. 2017;3(1):6899. http://doi.org/10.29313/kedokteran. v0i06899

24. Khoramipour K, Basereh A, Hekmatikar AA, Castell L, Ruhee RT, Suzuki K. Physical activity and nutrition guidelines to help with the fight against COVID-19. J Sports Sci. 2020;39(1):101-7. https://doi.org/10.1080/02640414.2020.1807089

PMid:32842905 